\title{
НАУКА И ОСВІТА В КОНТЕКСТІ СУЧАСНИХ ВИМОГ
}

\author{
Л. Г. Трусей \\ Харківський громадський фонд розвитку вищої освіти «Інтелект», директор.
}

Одним з основоположних принципів педагогіки є принцип науковості [1]. Без безперервного розвитку науки створити систему освіти актуальну часу неможливо. Відсутні фундаментальні наукові розробки загального характеру які б були фаховим інструментом в соціальній практиці. Окремі міждисциплінарні дисципліни не в змозі відповісти на всі питання сьогодення. Очевидно, на наш погляд, що деякий набір міждисциплінарних дисциплін системно об'єднаних на принципах міжсистемних взаємодій сформує достатній, з точки зору повноти, інструментарій вивчення та прогнозування соціальних явищ. Актуальність теми підкреслюється тим, що складність та швидкість змін соціальних процесів надалі буде збільшуватись [2].

Між тим, треба сказати, що в період, як на протязі 70 років соціалістичного ладу, так і протягом усього періоду української незалежності, спостерігалися і спостерігаються тенденції применшення значення досліджень філософського, соціального і в цілому всього комплексу гуманітарного напрямків в науці та освіті, підкреслювався їх нібито непріоритетний характер, їх «меншу відповідальність» в розвитку людства. Тому, в світі в цілому і в Україні зокрема, не було прийнято принципово нових організаційних і управлінських рішень щодо стимулювання розвитку цих напрямків в науці і практиці, що відповідає тому значенню, яке надається науці, освіті, науковому пізнанню людини, науково-технічному прогресу в життя суспільства. Крім того, в результаті помилкових ідеологічних і соціальних установок стало скорочуватися викладання і підготовка фахівців в гуманітарній сфері в багатьох навчальних закладах України.

Для загальної ситуації початку XXI століття було характерним відстоювання необхідності і правомірності напрямків досліджень в гуманітарній сфері знань часто попри те, що пропонувалося «зверху», ціною великих зусиль, розчарувань і навіть втрат нерідко талановитих людей. У зв'язку з цим вивчення методологічних, світоглядних і соціальних проблем розвитку науки, освіти і їх впливу на всі сфери життя суспільства, людини і людства набувають особливого значення. Стан справ тут не може задовольняти запити сучасного рівня розвитку суспільства. Осмислення новітніх досягнень науки, впровадження їх в навчальний процес неприпустимо затягується. Традиційно слабо розвиваються світоглядні проблеми гуманітарних наук. Тому перед суспільством стоїть цілий ряд надзвичайно важливих завдань.

Необхідно термінове підвищення рівня якості досліджень в гуманітарній області. Тут важливі не тільки високий рівень компетенції в розумінні найскладніших соціальних процесів, їх швидкоплинність і мінливість в житті людства, а й їх своєчасність. Оперативність значно підвищує ефективність як впливу на самі дослідження, так і на впровадження їх в навчальний процес і життя людей. Назріла нагальна необхідність появи нових ідей і теорій як основи, а також інструменту для теоретичної та практичної діяльності людей. Не менш важливим $€$ їх вивчення і застосування в житті. Необхідно, щоб ці питання стали предметом перш за все науково-педагогічних працівників.

Слід розуміти, що необхідний перехід від протиборства ідей та світових ідеологій до взаємодії, і ця тенденція повинна наростати. Сучасні засоби комунікацій — інтернет, радіо, телебачення, преса, інтенсивність прямих контактів людей різних ідеологічних орієнтацій неминуче підсилюють ці взаємодії. Тому нам важливо мати глибокі наукові розробки з цієї найважливішої проблематики сучасності не тільки для вирішення внутрішніх завдань, а й для успішного виправлення загальних світових проблем.

Велике теоретичне і практичне значення набуває завдання пізнання самої людини і перш за все іiі духовного світу. В даний час розгалужена система окремих наук досліджує різні сторони існування і розвитку людини. Необхідний же комплексний, системний підхід до пізнання людини як індивіда і особистості, носія духовності.

3 огляду на стан і перспективи розвитку людства в сучасних умовах початку третього тисячоліття, повинні піднятися на новий рівень дослідження в галузі глобальних гуманітарних і освітніх проблем людства. Особливо це важливо в умовах об’єктивного процесу глобалізації. Найважливішими з глобальних проблем сучасності $є$ ліквідація загрози існуванню людської цивілізації, збереження миру на Землі. Йдеться про те, що проблеми глобального масштабу, обумовлені в основному діяльністю самої людини, формують принципово новий феномен - систему глобальних проблем сучасності. Тут необхідно підкреслити, що мається на увазі розробка саме філософських, світоглядних, методологічних аспектів системи глобальних проблем. Так само виникає і активно розвивається напрямок наукових досліджень з вивчення глобалізації процесів світового розвитку.

Один з напрямків розробок філософії пов'язаний з областю теоретичного і практичного, методологічного і соціального обгрунтування моделювання процесів соціального, освітнього а також і насамперед глобального розвитку. Моделювання вирішує насамперед питання прогнозів розвитку та адекватності прийнятих рішень. У минулому для розуміння і прийняття рішень широко застосовувалися (особливо в області техніки - були 
спроби застосувати і для моделювання соціальних процесів) і використовувалися класичний дедуктивний і класичний експериментальний спосіб моделювання (його ще називали аналоговим моделюванням, коли експерименти проводилися з самим об’єктом, інша назва - моделюванням першого покоління). Далі з'явився метод математичного експерименту або іншими словами математичне моделювання [3]. Це методи другого покоління. Слід зазначити, що вирішити поставлену задачу моделювання дедуктивним або аналоговим методами не завжди вдається. Для скільки-небудь складних об'єктів і явищ це радше виняток, ніж правило. У той же час математичне моделювання, хоча і не призводить, як правило, до найкращого вирішення з усіх можливих (а лише 3 числа випробуваних) варіантів, часто застосовується на практиці. До появи методів моделювання третього покоління математичне моделювання було єдино можливим. Характерною особливістю математичного моделювання є те, що воно працює і в тих випадках, коли експерименти з реальними об'єктами сильно ускладнені, а часом і зовсім неможливі через складність об' єктів, велику вартість та реальної неможливості їх відтворення. Іншою особливістю математичного моделювання, що обмежує його застосування, є те, що математика працює з ідеальними об'єктами, які далекі від реальних (особливо якщо це стосується соціальних процесів). Сьогодні дуже часто керівнику, та й простій людині, при прийнятті рішень доводиться стикатися зі складними системами, що об'єднують в собі об'єкти різної природи. Облік різнорідних об'єктів математичними методами дуже утруднений (через неоднаковість розмірності). Крім того, для повного опису складної системи необхідно врахувати величезну кількість різнорідних параметрів, що іноді робить задачу нерозв'язною. Безперервно зростаюча складність об’єктів управління [4] робить абсолютно безперспективною практику прийняття рішень на основі лише досвіду і інтуїції без використання всієї потужності сучасного знання і теорій. Математичні методи мають також обмежену сферу застосування. Життя вимагає появи нових теорій, нового знання.

Виняткову важливість і актуальну значимість в усій масі наукових досліджень набуває проблематика розвитку, що служить необхідною умовою розуміння сучасного стану людства і перспектив його в майбутньому. Звідси - необхідність в розробці і систематизації проблематики розвитку, уточнення на сучасному рівні іiі концептуального, понятійного змісту, їі онтологічних основ. Дійсно, філософська теорія оперує складними поняттями високого ступеня філософської абстракції, смислове навантаження і зміст яких, проте, залишаються не зовсім проясненими для практичного розуміння і застосування в житті. Класична філософія визначає розвиток як необоротну, спрямовану, закономірну зміна матеріальних та ідеальних об’єктів. Однак універсальне поняття розвитку ще не вироблено. Проблематичне утвердження незворотності і спрямованості зміни в процесі розвитку, якщо відомо, що прогресивний розвиток завжди переплітається з відхиленнями або навіть 3 регресивними явищами. Різні трактування поняття розвитку дають сучасні вчені, такі як Х. Хорстман, Е. Рамбальді, М. Гіс, Х. Зандкюлер, Н. І. Лапін, В. П. Бабич та інші. Наприклад, М. Гіс висловив думку про те, що провідну роль може і повинна грати діалектика: але здійсненне це лише в тому випадку, якщо вона буде не негативною, а позитивною, в гегелівській термінології - діалектичної онтологічної логіки (логіки буття). Більш адекватний опис парадигми розвитку може дати, на що вказав Х. Зандкюлер, лише (онто-логіка), бо, по-перше, зміст буття не може існувати без логічної форми, і, по-друге, зміст буття не відокремлений від логічної форми. Онтологічне розуміння явища розвитку дані в роботах В. П. Бабича $[5,6]$.

Особливе місце в теоретичних дослідженнях сучасності надається створенню теорії систем. Над цією темою працювали багато вчених і при цьому отримали ряд важливих результатів. Так А. Н. Авер'янов провів аналіз практики в світлі системних уявлень як специфічної взаємодії суспільної людини зі світом, утвердження людини в світі. Він свій філософський пошук вів у напрямку системного осмислення соціальної реальності, обгрунтування методів дослідження соціальних явищ, збору та узагальнення соціальної інформації, проблем iii достовірності та істинності соціального знання. Однією з особливостей досліджень А. Н. Авер'янова є системне дослідження проблематики сучасного суспільства, осмислення суспільного розвитку в сучасну епоху в цілому, пов'язане з досягненнями НТР, гострими соціальними колізіями, протиборством сил світу і війни, аналіз прогностичної функції соціально-філософського знання [7] . Онтологічне розуміння явища розвитку дані в роботах В. П. Бабича [5, 6]. Роль наукових досліджень соціальних явищ в суспільстві важко переоцінити. Ці дослідження повинні стати основними на етапі переходу людства в епоху цивілізації [5]. Інтерес до таких досліджень визначається передусім масштабом і практичною необхідністю. Особлива роль відводиться міждисциплінарним дослідженням, які по суті об’єднують знання, методи, засоби і передові навики ученихфахівців різних напрямів у вивченні загального для них об’єкту - соціальних явищ. Міждисциплінарні дослідження - найважливіша відмінна риса і характерна особливість сучасної науки і також вимога соціальної практики [8]. Тільки до кінця ХХ століття стало ясно, що вузькоспеціальні науки, вузький дисциплінарний підхід не дозволяє ні вивчати, ні зрозуміти усі соціальні процеси, які ускладнюються. В. І. Вернадський говорив про зростаючу складність і масштабність великих проблем в житті людства і розвитку наукового знання [9]. Їх не можна вирішити силами окремих наук, наскільки б узагальненими вони не були. Дослідження реальних соціальних систем окремими частинами окремими науками не дає адекватного їх розуміння і пояснен- 
ня. Саме міждисциплінарний підхід дає можливість утілити вимогу часу про цілісне вивчення явища, його елементів, взаємодій елементів, а також на рівні міжсистемної взаємодії $[6,10]$.

Враховуючи, що ріст складності реальних теоретичних і практичних завдань набагато перевищує за своєю швидкістю зростання особистих можливостей окремо взятої людини, то проблема створення додаткових можливостей підтримки людини нині виникає в усіх життєво важливих сферах діяльності. Особливо гостро ця проблема стоїть в розумовій діяльності. Вона зажадала зміни стереотипу мислення і створення нових, загальніших підходів до розуміння дійсності. Окрім складності завдань, що стоять перед людством, існуюча базова сукупність глобальних ідей, пов'язаних з розумінням світу людиною і свого місця в нім неминуче повинно кардинально змінитися. Такі зміни потребують появи нових глобальних універсальних філософських концепцій і напрямів, що відповідають по рівню своєї загальності, мірі розробленості, проблематиці моделювання, можливостям формалізації і широті предметної області духу часу. Окремі дослідження не об'єднані загальним вектором практичної направленості наукових розробок. Тому стоїть нагальна потреба введення в концептуально-понятійне середовище гуманітарних дисциплін таких міждисциплінарних теорій, які спроможні ефективно формувати нові стереотипи мислення, що характерні для людини третього тисячоліття i, як наслідок цього, процесу світорозуміння і системної організації своєї безпосередньої діяльності.

Якщо виділити приклади досліджень в цьому напрямі нині, то обмежимося розглядом і загальною характеристикою трьох абсолютно нових наукових дисциплін — це загальна методологія (методологія більш високого філософського рівня), прикладна онтологія і системні методи третього покоління. Названі напрямки наукових досліджень зараз уже заявили про себе. Але про них знає дуже вузький прошарок спеціалістів. На наш погляд, задача полягає в тому, щоб ці знання стали надбанням широкого загалу, зокрема для спеціалістів, які займаються соціальною практикою та управлінською діяльністю, а також щоб ці наукові дисципліни стали інструментом розуміння і опису складних соціальних процесів сучасних і майбутніх суспільств, що обумовлює їх подальший розвиток.

Причини появи загальної методології полягають в наступному: жодна з окремих наукових дисциплін не може представити ії̈ в готовому виді, здатною до застосування іншими; відсутні єдина наукова мова, термінологія, система критеріїв; фактично немає наукових праць за загальною методологією; відсутній системний підхід в осмисленні загальної методології; немає таких загальнонаукових засобів як моделювання, яке по суті $€$ ядром інтеграції наукових знань; не залучені до загальної методології такі нові поняття і концепції, як синергетика, ноосфера, онтологія, екологія, значення людини, тобто як повернути в систему суб'єкт діяльності (людський чинник); немає підходу до аналізу і вирішення складних глобальних проблем. Загальна методологія включає як метод прикладну онтологію і системні методи третього покоління.

Причини появи прикладної онтології полягають в наступному [5]: скорочення гуманітарних дисциплін в системах середньої і вищої освіти; ускладнення соціальних процесів і не здатність сучасної науки їх адекватно пояснити; перехід людства в штучну епоху — епоху цивілізації, яка зажадала наукового обгрунтування закономірностей земного буття людини; розширення відповідальності людини за свої дії до глобального рівня. Фактично прикладна онтологія - це філософія, спущена з далеких висот до практичного застосування людиною в сучасному житті з усуненням абстрактних узагальнень і властивих філософії істотних обмежень як загальної науки.

Причини появи системних методів третього покоління (теорія гіперкомплексних динамічних систем або інше найменування дисципліни - інваріантне моделювання) [11] полягають в наступному: відсутність нових теорій світоглядного рівня; відсутність нових (застарілі не годяться) технологій соціального будівництва; вузькоспеціальна підготовка в системі освіти; відсутність наукових методів дослідження аномальних явищ; відсутність наукового інструментарію охоплення розумінням загального і можливостей синтезу; немає наукової основи підготовки поля функціональних фахівців, особливо у сфері управління; немає науки, яка вивчає діяльність як таку; відсутність досить повного набору фундаментальних принципів і закономірностей, що відносяться саме до систем і тим самим виділяють їх як специфічний об'єкт і предмет дослідження; велика кількість підходів і методів об'єднаних поняттям «система» зумовило необхідність створення наукового напряму, предметом якого стали власне системи, їх основні закономірності і властивості; не вирішено завдання адекватності наукового тлумачення соціальних процесів; відсутність взаємодії природознавчих, гуманітарних і технічних наук, об'єднаних єдиною метою; відсутність досліджень по вивченню так званого «комплексного підходу» (насправді системні методи третього покоління включають і поняття комплексного підходу); відсутність інструментарію вивчення глобальних проблем. Помилково вважається, що системний, комплексний і глобальний підходи представляють різні рівні міждисциплінарності, що відображають зростаючу складність соціальних проблем, які стоять перед людством. Насправді системні методи третього покоління включають усі підходи і тому є універсальними. 
На основі вищесказаного, завдання дослідження полягає в загальній характеристиці запропонованих трьох міждисциплінарних дисциплін, окреслення областей їх застосування, а також можливостей їх взаємодій та подальшого розвитку.

Загальна методологія. Загальна методологія покликана виробити єдиний загальнометодологічний підхід, який синтезував би результати різних напрямів методологічних досліджень. Філософія, як основа методології, грає велику роль в міждисциплінарних дослідженнях, тому подальший розвиток самої філософії, подолання певних обмежень іiі категорій дозволить зміцнити їі зв'язок з іншими окремими науками в методологічному сенсі. Загальна методологія покликана стати головним інструментом рішення в першу чергу глобальних проблем, які стоять на першому плані діяльності людини і ставлять перед нею дуже серйозні виклики. Загальна методологія покликана розв'язати проблему методологічної неповноти і несумісності методологій окремих дисциплін. На нашу думку, загальна методологія може стати об'єднуючим фактором методологій інших дисциплін як універсальний інструмент практичної діяльності людини. Приведемо визначення загальної методології. Загальна методологія - це система принципів та способів (методів) побудови та організації теоретичної та практичної діяльності людини та людства в цілому. Кожне слово в цьому визначенні має дуже важливе значення. Слово «система» означає, що принципи і способи об’ єднані системними взаємодіями, сформовані в структуру, мають цілісність 3 новою якістю, якої не мали елементи системи. Крім того, ієрархічний рівень загальної методології стає найвищим. Тобто, рівень системної організації загальної методології повинен бути не нижче п'ятого рівня. Подальші вивчення та розробки теорії загальної методології повинно врахувати вищесказане і підняти їі на самий високий рівень міждисциплінарних теорій.

Прикладна онтологія [5]. Нова галузь науково-прикладних знань про суть, сенс і цілі земного буття людини і його розумну взаємодію з навколишньою природою. Ця галузь світової науки покликана визначити основні етапи еволюційного розвитку інтелектуальних і духовних здібностей людини, дати об'єктивну цілісну картину сучасного світу з усіма їі позитивними і негативними явищами і тенденціями, всебічно обгрунтувати найбільш вірогідні перспективи подальшого впорядкування життєдіяльності людей на земній планеті. Прикладна онтологія покликана «з’єднати те, що раніше не з’єднувалося», а значить сформувати двоєдину загальнолюдську, достовірну наукову концепцію духовно-матеріалістичного пізнання світу. Дух і матерія розглядаються не як протиборчі першооснови, а постійно взаємодіючі, взаємодоповнюючі і взаємозбагачувальні складові земного життя і діяльності кожного індивіда-землянина і усіх мешканців нашої загальної планети. Прикладна онтологія відкриває реальні можливості пізнання первинних витоків неповноцінності і порочності багатоликих систем індивідуального, кланово-групового і суспільно-політичного світогляду, що стихійно сформувалися. 3 іншого боку, прикладна онтологія є науковим потенціалом, спрямованим на формування універсальної загальної земної системи цивілізованої і збалансованої побудови матеріального і духовного буття людини в умовах загального ненасильницького світу. Сьогодні роль прикладної онтології про перегляд картини світу і місця в нім людини стоїть як ніколи гостро і повинна грунтуватися на новому антропологічному принципі - миследіяльності (на російській мові - «мыследеятельности»). Діяльність людини в ХХІ столітті - це головне завдання як науки, так і кожної людини, як земного мешканця.

Об’єднувальну функцію консолідації і координації безлічі наукових розробок і досліджень сучасних проблем глобалізації світу повинна виконати прикладна онтологія, як особлива галузь наукових знань про основні закони еволюції і найбільш раціональний уклад життя і діяльності людей на земній планеті. У минулому така галузь науки не могла виникнути в силу природної обмеженості людського інтелекту і повсюдного панування різноманітних і несумісних національних, релігійних і кланово-групових інтересів, традицій і переваг [6].

Сучасна історія ультимативно спонукає усіх землян розширити горизонти бачення світу до загально-земних проблем існування суспільства і навколишньої природи. Настав час для кожної сучасної цивілізованої людини міцно усвідомити, що від успішного рішення цих глобальних проблем безпосередньо залежить історична доля людства і кожного землянина в XXI столітті і третьому тисячолітті нашої ери. Якщо попереднє століття називають століттям науково-технічного прогресу і кардинального поліпшення матеріальних умов земного буття, то XXI століття повинне привнести до історії людства не менш значимі досягнення в області науково-інтелектуального прогресу і еволюційних перетворень духовного життя усіх прийдешніх поколінь людей.

Створення науково-теоретичних основ прикладної онтології в найближчій перспективі дозволить залучити усіх людей до знань, специфіки об'єктивних загальнолюдських законів і вимог, а в той же час дозволить привести їх суб'єктивні, часто егоїстичні, інтереси і пристрасті в належну відповідність загально-земним нормам розумного, цивілізованого мислення і поведінки на нашій загальній планеті.

Системні методи третього покоління [11]. Ці методи розроблені на усіх можливих рівнях представлення наукових теорій: вербальному, символьному (формалізованому), алгоритмічному, 3 можливістю ЕВМ реалізації, ігровому. Це знання завтрашнього дня. Це новий міждисциплінарний підхід, що дозволяє будувати 
системні моделі і проводити міждисциплінарний аналіз складних об’єктів, процесів і явищ незалежно від їх фізичної природи. Служить фундаментом для побудови ідеології, яка претендує на роль нової світоглядної основи людини третього тисячоліття. Може застосовуватися на стиках науки, релігії, культури, аномальних явищ і езотеричних знань. Має здатність ефективно формувати нові стереотипи мислення, характерного для людини третього тисячоліття, у якого активізується процес світобачення і системної організації своєї безпосередньої діяльності. Основні положення системних методів третього покоління є корисними, а іноді і обов'язковими для управлінців різного рівня, яким необхідно швидко орієнтуватися і приймати відповідальні рішення в складних ситуаціях нашого часу.

Існують і інші приклади міждисциплінарних досліджень, нас же більшою мірою цікавлять наведені вище.

Проблеми освіти носять онтологічний характер тому, що ми не цілком розуміємо складнощі сучасного світу і ролі в ньому людини. Змінився і продовжує змінюватися характер існування людини і темпи цих змін все збільшуються. Перехід від епохи варварства до епохи цивілізації [5], який ми зараз переживаємо, зажадає людей зовсім іншого типу, що мають абсолютно інше мислення, що працюють в інших індустріях і мають інші набори навичок.

Особливої актуальності набуває проблема освіченості людини і її природи в цей історичний період, коли повинно практично вирішуватися питання «Бути чи не бути... людству?». «...Ми маємо справу завжди і перш за все з людським феноменом, тобто з нашим реальним життям, коли думаємо про нього не в термінах існуючих теорій і інституцій (що мають свої теорії), а в термінах власного життя і в контексті його проблем ...»писав М. К. Мамардашвілі [12].

Початок нового століття і тисячоліття приносить чітке розуміння і усвідомлення головного завдання науки і освіти: дослідження та становлення внутрішнього духовного світу людини. Без такого розуміння Універсуму і людини, здійснення практичних результативних дій в даному напрямку навряд чи можна знайти реальні шляхи виходу з заглиблюваної глобальної кризи сучасності. Одухотворення, олюднення дійсності сьогодні стає рівнозначним виживанню і порятунку людства. Перед вченими і всіма землянами встало фундаментально-рятівне питання: чи готові ми «прийняти єдність науки і духовності» [13].

Ю. Ротенфельд пропонує новий підхід до шкільної освіти, що збирає знання в голові дитини, як з предметів, так і міжпредметны, за принципом, що дозволяє навчати дітей не тільки розумному мисленню, а й філософській мудрості, націленій на пізнання найбільш загальних відносин дійсності. В результаті більш розумні школи означають більш розумних вчителів, більш розумних дітей і їх батьків, нарешті, більш мудру владу, турбота якої не панування над суспільством, а служіння йому [14]. Розумовим мисленням користуються всі гуманітарії. Розумне мислення використовують представники природничих наук. Мудрість як спосіб осмислення найбільш загальних законів розвитку природи, суспільства і мислення зупинилася в своєму розвитку на рівні античності, оскільки філософи втратили їі специфічні понятійні засоби — конкретно-загальні порівняльні поняття різних видів.

Фактично, мова йде про новий вигляд філософії, яка відрізняється від всіх колишніх філософських напрямків своїм накопичувальним характером (кумулятивний) за рахунок використання нового понятійного апарату - натурального ряду порівняльних понять, спрямованих на пізнання все більш загальних відносин дійсності. В результаті філософія стає об’єктивною наукою, подібною іншим природничим наукам.

Новий підхід до філософії освіти дозволяє осмислювати суспільство не за допомогою безлічі суб'єктивних думок, що змушують людей жити в різних соціальних світах і по-різному розуміти суспільство. А з однакових для всіх об'єктивних точок зору, що призводить не тільки до розуміння суспільних процесів, але і до взаєморозуміння між людьми. На цій основі пропонується змінити підхід до шкільної освіти. Якщо зараз вона розколота за предметним принципом, і кожен предмет маленькими шматочками закладається в голови дітей, а вже 3 них знову збирається розколоте з предметів знання. То новий підхід, навпаки, буде збирати шкільне знання не тільки за предметним, а й за міжпредметним, панлогічним принципом. Головне в новому підході полягає в тому, що філософія, як «знання загального» формує науково обгрунтовану цілісну картину світу і з цим знанням приходить в загальноосвітню школу, щоб навчати дітей не тільки окремим знанням, а й мудрості. Тому «розумніші школи означають більш розумних майбутніх батьків як більш розумних громадян» (М. Ліпман), більш розумних викладачів гуманітарних і соціальних наук, більш прийнятних журналістів і політиків, а в підсумку більш розумну і мудру владу [14].

Зі сказаного випливає розуміння того, що вихід-виживання вимагає кардинально якісної зміни моральності і якостей кожної людини. Усвідомлення цього можна досягти, як один із напрямів, створенням абсолютно нової системи освіти. Базовий перехід (якого не відбулося) до нової системи освіти повинен грунтуватися на ситуаційному аналізі сучасної освіти. Його в повній мірі не озвучили досі. У зв'язку з цим основні тези такі:

Накопичена величезна кількість інформації в кожній галузі знань, яку в принципі неможливо дати учням за відведений період для освіти. Встановлено (зокрема вченими Японії), що інформація, ідеї, технології і т. п. 
застарівають кожні 5-10 років. Моральне становлення підростаючого покоління не відповідає сучасним складнощам земного буття людини [15].

Ускладнення всіх сторін життя людини зажадало нового рівня вимог до випускників — це поліфункціональність, професійна підготовка (напр., сучасний випускник ПТУ прирівнюється до інженера першої половини XX століття), особливо високі вимоги до моральних і психічних якостей і т. п. Вчити всіх усьому [5].

Одна з характеристик сучасності полягає в тому, що нові технології вже витіснили з сільського господарства і промисловості більше 2/3 зайнятих працівників і в XXI столітті цей процес буде ще більш посилюватися. Чисельність працюючих людей впаде на порядок.

Якщо сформулювати основну мету системи освіти, то вона виглядає так: створити нову людину. Освіта і виховання це єдиний процес. Розділивши систему освіти на дві складові, ми маємо мету освіти - освіта повинна вказувати що корисно, обов'язково, добре, мета виховання - знайти рушійні сили для ефективного виконання засвоєного в першій частині. Узагальнюючи сказане сформулюємо триєдине завдання освіти на сучасному етапі розвитку людства (всебічний розвиток наступних якостей особистості - представлених по пріоритету): психічні здібності (риси характеру); індивідуальні особливості; інтелектуальні здібності. Необхідно згадати забуте поняття відання (в російському варіанті — «ведание»). Його потрібно повернути в систему освіти. Відання означає — знати, розуміти, вміти виконати (зробити).

На яких засадах будується система освіти? Знання як такі не є предметом бажання, тобто вже сам факт отримання знань в сучасних умовах не є побудженням. Побудженнями для сучасної молоді являються: бажання отримати гарну оцінку (закінчити школу з високим балом і поступити в інститут); бажання віконати наказ батьків (учителів) або щоб зробити приємне батькам; бажання відчути і зрозуміти навколишній світ (об'єктивну реальність); бажання виділитися серед однокласників, знайомих, сусідів, перед кимось особисто; бажання освоїти певну професію і отримати престижну роботу або зайнятися підприємництвом та ін.

Дуже важливі і головні, на наш погляд, спонукальні мотиви, як би це не звучало пафосно (ми в ідеалі повинні прагнути саме до цього), мають бути наступні [5]: відчути любов до реальності (тобто до Світу, що оточує нас, Природи, Всесвіту) і бажання пізнати їі і своє місце в ній. Учителеві треба зробити так, щоб учневі було що любити і щоб в об'єкті любові було закладено добро; бажати осягнути істину — це усвідомлення необхідності прямого контакту з реальністю, означає любити, тобто повністю перебувати в істині, якою б вона не була, відкинувши усі умови. Будь-яка інша любов бажає, передусім, задоволення, будучи основою для помилок і брехні.

Про стимули. Вже давно придбання нових знань не є достатнім стимулом в наполегливості учнів. Потрібні інші стимули: деякі знаходять їх в самому учбовому процесі: цікаво вчитися (усі так роблять); захоплення красою реальності в предметах, що вивчаються; думка про майбутнє, про впровадження своїх знань в реальному житті; думка про приналежність до великих подій у світі і країні; бажання допомогти своїм близьким, особливо батькам, майбутньою своєю діяльністю; бажання вибратися з убогості, 3 нижчих верств суспільства у вищі; бажання отримати чисто матеріальні вигоди (будинок, машину і тому подібне); соціальні стимули, тобто змінити положення народу, соціального шару і усього людства; схильність моді (правда істинні причини глибші), тобто в певні періоди часу були модними інженерні спеціальності, потім торгові і громадського харчування, далі юридичні, економічні і так далі.

Крім того існують і інші стимули: просування, кафедри, винагороди, шана і гроші, прийоми і поїздки за кордон, репутація, популярність, звання, колективні думки та інші. Головний стимул на наш погляд - це творити добро, зробити щасливим життя близьких і тих людей, які оточують.

Освіта, виховання - єдиний засіб, який ми маємо, щоб впливати на духовний стан і буття народу. І сумно констатувати, що в Україні, особливо в органах державної влади, немає нікого, хто б міг зрозуміти, що наша сучасна освіта і виховання являють собою небезпечний елемент швидкого занепаду, і замість того, щоб розвивати нашу молодь, вони все перекручують і ведуть до загальної деградації підростаюче покоління. Складається враження, що сучасні потуги можновладців по «реформуванню» системи освіти спрямовані на регрес освіти нашої молоді, що в принципі логічно суперечить основним цілям цивілізаційного розвитку суспільства [16].

Твердження про те, що освіта вирішить багато наших проблем, є непохитним догматом демократії. Насправді демократична ідея в області освіти опинилася в повній розбіжності з даними психології і досвіду. Багато філософів, психологів і аналітиків довели, що освіта, особливо в тому вигляді, в якому вона організована нині в Україні, перешкоджає формуванню людини моральнішою, щасливішою і не змінює ні їі інстинктів, ні їі спадкових ознак. Іноді навіть, якщо освіта організована не відповідно до вимог цивілізаційного розвитку суспільства, завдає більше шкоди, ніж користі. Дані статистики підтверджують, що злочинність збільшується разом з узагальненням освіти або відомої статичності (без розвитку) мотивів, змісту і методів освіти.

Поза сумнівом, правильно поставлена освіта, особливо їі друга частина — виховання, може дати дуже корисні практичні результати, як в сенсі підвищення моральності, так і в сенсі розвитку професійних здібностей. 
Постійно зростає невідповідність між нашою освітою, вихованням і потребами життя [17]. Якщо спробувати визначити мету існуючої системи освіти, можна зробити єдиний висновок: мета — отримати примітивних, слухняних виконавців (рахуй біороботів), що не розуміють загальних світоглядних тенденцій і закономірностей розвитку суспільства.

На жаль, наша освітня система грунтована на наступних неправдивих принципах, а отже і неправдивих практичних втіленнях: вона спирається на ту основну помилку, ніби заучуванням на пам'ять інформації, об'єми якої все збільшуються, розвиваються розумові здібності людини; набір інформації, що дається при навчанні, не об'єднується у світогляд і світобачення; максимальне усунення педагога від учбового процесу і використання при цьому технічних засобів навчання, різних форм тестування, можливості яких обмежені визначенням тільки частини завченої інформації; зменшення годин на гуманітарні, філософські та інші, чисто світоглядні дисципліни; не розвивається здатність до міркування, творчості; ініціатива учнів, студентів ніскільки не підтримується та не тренується; головна ж небезпека в тому, що вона вселяє тому, хто отримав освіту і виховання, відторгнення до умов свого громадського положення, так що селянин вже не бажає бути селянином, робітник - робітником, багато хто прагне обійняти посади високооплачувані, стати чиновниками, бути обраними в органи влади, стати «зірками», «моделями» і тому подібне; у всьому, що пропонується дітям для вивчення, особливо при вивченні історії, добро зневажається; інформаційний бум, що переживає людство, призводить до безуспішності екстенсивної освіти, що намагається поспіти за постійно наростаючим об'ємом інформації. Шкільні програми, а услід за ними і діти стають неприпустимо переобтяженими. Це тупіковий шлях розвитку освіти.

Молоді люди впродовж порядку десяти років в школі, п’яти років в інституті, далекі від безпосереднього особистого досвіду, який міг би дати їм точні і глибокі поняття про речі, людей і різні способи поводження 3 ними і притому в такі роки, які вважаються найбільш дієвими, важливими і навіть вирішальними. Замість того, щоб підготувати молодих людей до життя, школа, вищі навчальні заклади готують їх до зайняття посад, де можна досягти успіху, не проявляючи ані найменшої ініціативи і не діючи самостійно. Така освітньо-виховна система вже підготувала цілу армію невдоволених своєю долею людей, які характеризуються наступним: а) люди готові до обурення; б) постійно звинувачують уряд у своїх власних помилках, крім того, ситуація посилюється антинародною політикою, що проводиться державою, великим розривом між декларованою $\mathrm{i}$ об’єктивною моральністю; в) люди рішуче не здатні зробити що-небудь без втручання влади. Держава, що готує величезну армію дипломованих фахівців, може використати з них дуже невелику кількість, залишаючи усіх інших без жодної справи, і таким чином вона (держава) живить одних, а в інших створює собі ворогів.

Книги - це словники, дуже корисні для наведення довідок, але абсолютно марно зберігати у своїй голові довгі уривки з них; молоді люди позбавлені дорогоцінного сприйняття, зіткнення з елементами життя, які легко засвоюються і являються необхідними, і притому позбавлені вони цього в найпліднішому віці. Придбані молодими людьми знання, занадто численні, об'ємні, безперервно зникають з їх пам'яті, через місяць після іспиту вони вже не в змозі їх повторити, нових же знань вони не надають; від такого отримання знань сила молодих людей ослабляється, плодоносні соки ії вичерпуються, перед нами людина вже готова обертатися в одному і тому ж крузі, вона замикається у вузьких межах свого життя, часто виконує свої обов' язки коректним чином, але далі цього не йде. Відкладається практична сторона навчання, штучні ж вправи, механічне набивання голів непотрібними в житті відомостями, призводить тільки до перевтоми. Не береться до уваги той реальний світ, куди повинна вступити людина, ні суспільство, що оточує іiї, ні життєві зіткнення, до яких людина має бути підготовлена, укріплена і озброєна.

На основі викладеного можна сформулювати завдання, яке полягає в розробці напрямків створення абсолютно нової системи освіти, яка б відповідала вимогам переходу до епохи цивілізації в XXI сторіччі.

\section{Особливості рекомендованої системи освіти.}

Педагогіка. Виклик часу — перейти від кодуючої фактологічної (фактично, цитатно-догматичної) педагогіки до методологічної педагогіки (МП), яка ставить перед собою принципово інші цілі: людина - це, передусім, певний лад психіки. Формування ладу психіки «людина розумна» і повинно лежати в основі МП. Добре навчений розумний мерзотник може бути більш небезпечний для суспільства, ніж неук, а усі зусилля учителів будуть зведені нанівець; освіта — це не лише набір знань, але передусім і світогляд, який дає дітям знання про життя, про добро і зло; МП повинна давати наступні практичні навички:

а) здатність розрізнення, тобто здатність виділити з великого масиву інформації корисну і важливу на фоні менш важливої і некорисної, нині домінуючої в 3МІ;

б) здатність до цілісного, мозаїчного сприйняття явищ буття в їх взаємозв'язку;

в) здатність розрізняти добро і зло; 
г) усвідомлювати сучасні методи егрегоріально-матричного управління, зомбування свідомості і підривання генетичного потенціалу народу;

д) здатність осмислено протидіяти підриванню генофонду і перетворенню людей в зомбі - біороботів;

е) на світоглядному рівні відсторонюватися від генної зброї, такої як алкоголь, тютюн, наркотики, комп’ютерна і телевізійна залежності, спеціальний вид музики;

ж) здатність формувати пріоритети цілей і вектор цілей управління громадськими і приватними процесами у своїй сфері діяльності;

3) здатність розрізняти приналежність будь-яких приватних засобів і чинників дії на суспільство до того або іншого пріоритету узагальнених засобів управління добробутом, життям і діяльністю суспільства;

Методологічна педагогіка здатна: прищепити, передусім, навички і методологію (інструмент) освоєння нових знань; інформаційну адаптацію до місця своєї роботи слід покласти на саму методологічно грамотну людину; перейти від кількісних змін до змін якісних.

Особливості освіти: навчають не стільки книги, а, передусім, самі предмети. Після отримання певних базових знань, а краще всього і в ході їх отримання, практичну освіту здійснювати безпосередньо в майстерні, на заводі, в полі, в лікарні, у архітектора, адвоката і тому подібне. Практичні здібності людини збільшуються і розвиваються самі собою і в такому ступені, який відповідає іiі природним даруванням, і в напрямі, потрібному для їі майбутньої діяльності. Фактично стати не лише машиною, а, передусім, двигуном; формувати навички планування свого часу; сучасна система освіти повинна будуватися так, щоб:

а) колективами учнів не пригнічувати індивідуальність [18] (звідси, у тому числі, витікає вимога до мінімальної кількості учнів, студентів);

б) при виявленні (а до цього повинен прагнути кожен учитель, педагог) індивідуальних особливостей, вони мають бути центром роботи.

Особливості виховання : професійне виховання має бути спрямоване на те, щоб повернути нашу молодь до поля, верстата, майстерень, цехів на підприємствах, що уникають їх усіма засобами нині. Це професійне виховання було у нас у минулому; розум, досвід, ініціатива і характер (психічні ознаки) - ось умови успіху в житті.

Організаційні, управлінські, фінансові особливості. Усі форми освіти - безкоштовні. Повинна бити створена єдина державна система перепідготовки кадрів, що охоплює усі вікові групи від молодих людей до старших, однаково доступна для вихідців з усіх верств суспільства.

Час базової середньої шкільної підготовки скоротити до 8-9 років. Особлива роль відводиться сім’ї, де фактично і відбувається становлення особистості дітей.

Основою є вищий пріоритет управління - методологічний (світоглядний).

Управління дошкільною і шкільною освітою здійснюється на рівні місцевих громад наступними органами: Опікунською Радою; Батьківським Комітетом; Педагогічною Радою. Тільки вони вирішують усі питання життя і діяльності дошкільних і шкільних установ, у тому числі які предмети і їх об'єми викладати.

Для вищих учбових закладів надається повна самостійність і автономія. Ліцензування і акредитація відміняються. Авторитет учбового закладу формується батьками, що бажають віддати свою дитину в конкретний учбовий заклад.

Для батьків і їх дітей встановлюється безкоштовна освіта. Процедура наступна: в річному бюджеті України виділяються необхідні суми грошей на кожен рівень (дошкільна, шкільна, вища) освіти; гроші виділяються конкретній дитині; розпоряджаються грошима батьки, тобто вони вирішують в який учбовий заклад внести гроші на освіту своєї дитини; для підготовки конкретних фахівців для конкретних громад, підприємств, корпорацій і тому подібне можливе спонсорське, цільове і грантове фінансування, яке є допоміжним.

Вимоги до педагогічних кадрів: щоб закликати до досконалих вчинків і життя, педагогові треба самому стати досконалим; знати і уміло застосовувати методологічну педагогіку; знати основи егрегоріального управління і використати його в повсякденній педагогічній практиці; знати потоки інформації, що поступають в психіку дітей, знати і мати навички корекції потоків і перерозподілу пріоритетів; в повному обсязі освоїти методологію.

\section{Висновки}

Створивши освіту як систему на основі запропонованих ідей з відповідним доопрацюванням, ми зуміємо підготувати людей завтрашнього дня, тобто людей епохи цивілізації [5]. Вже на підставі наведеного аналізу можна зробити наступні висновки:

1. Фактично застосовувана в сучасній системі освіти цитатно-догматична (фактологічна) педагогіка віджила свій вік і не дозволяє готувати молоде покоління до життя.

2. Створюючи нову (не реформуючи стару — вона мертва) систему освіти потрібно будувати їі зовсім на принципово інший педагогіці - педагогіці методологічній. Суть їі полягає в першу чергу в дачі методологічних знань - знань як інструментарію отримання нових (будь-яких) знань. 
3. Сьогодні роль Прикладної Онтології, інших гуманітарних, природних наук i, передусім, філософії про перегляд картини світу і місця в нім людини стоїть як ніколи гостро. Макс Шелер [19], Гроф К., Гроф С. [20], Тейяр де Шарден[21], Рассел Б. [22], Фукуяма Ф. [23] і інші писали про феномен людини і іiї місце в реалізації майбутнього як самої людини, так і людства в цілому. Розвиток науки в цьому напрямі повинен грунтуватися на новому антропологічному принципі — миследіяльності людини. Йдеться про освіту, заснованому на «пробудженні свідомості», як радив Лев Толстой [24]. Діяльність людини в XXI столітті — це головне завдання як науки, так і кожної людини як земного мешканця.

4. Розробляється концептуально і програмно система духовно-інтелектуального виховання і освіти (ДИВО-21) групою вчених яка покликана започаткувати справжню, відповідно реаліям XXI століття, освіту.

\section{Література}

1. Фіцула М. М. Педагогіка вищої школи. Вид. 2-ге, доповнене. Академвидав, 2014.

2. Трусей Л. Г., Трусей Л. М. Соціальні проблеми наукових досліджень // Вісник Національного університету «Юридична академія України ім. Ярослава Мудрого», Філософія, Філософія права, Політологія, Соціологія, 2017. № 1 (32).

3. Глушков В. М. Математизация научного знания и теория решений // Вопросы философии, 1978. № 1. 28 с.

4. Вернадський В. І. Наукова думка як планетне явище / під ред. Яншина А. Л. М.: Наука, 1991.

5. Бабич В. П., Могилко В. А., Онєгіна В. М. Прикладна онтологія — Харків.: Мадрид, 2013.

6. Проблеми і перспективи науково-онтологічних знань : препринт наукової доповіді Харківського інституту управління / Бабич В. П. та ін. Харків, 2011.

7. Аверьянов А. Н. Системное познание мира. М. : Политиздат, 1985.

8. Фромм Э. Здорове суспільство. М. : АСТ, 2009.

9. Вернадський В. І. Наукова думка як планетне явище / під ред. Яншина А. Л. М.: Наука, 1991.

10. Задорожный Г. В., Задорожная О. Г. Людина господарююча: онтологічні підстави цілісної добрісної життєдіяльності в глобальному кризовому світі : препринт доповіді на міському міждисциплінарному семінарі. Харків, 2016.

11. Малюта А. Н. Гіперкомплексні динамічні системи. Львів. : Выща школа при Львівському держ. університеті, 1989.

12. Мамардашвили М. К. Из лекций по социальной философии // Социологический журнал, 1994. № 3 ,

13. Талбот А. Голографическая вселенная. М. : Изд. София, 2005.

14. Ротенфельд Ю. Мудрая школа, «Трилогия ума». Электронная книга.

15. Симона Вейль. Укоренение. Письмо клирику. К. : Изд. «Дух и Литера», 2000. 350 с.

16. Карл Ясперс. Сенс і призначення історії. М. : Республіка, 1994.

17. Дарио Салас Соммэр. Мораль ХХІ віку. К. : Софія, 2004.

18. Поль Рикер. Сам як інший. К. : Дух і Літера, 2000.

19. Шелер М. Формы знания и образование // Человек. Вып 4. М., 1992.

20. Гроф К., Гроф С. Духовный кризис: когда преобразование личности становится кризисом. М. : ООО «Издательство ACT», 2003.

21. Тейяр де Шарден П. Феномен человека : сб. очерков и эссе / пер. с фр. М. : ООО «Издательство АСТ», 2002.

22. Рассел Б. Избранные труды. Н. : Сиб. университетское изд., 2009.

23. Фукуяма Ф. Доверие: социальные добродетели и путь к процветанию / пер. с англ. Д. Павловой, В. Кирющенко, М. Колопотина. М. : ООО «Издательство АСТ» ЗАО НПП «Ермак», 2004.

24. Толстой Л. Н. О народном образовании : в 22 т. М. : Худ. лит. 1983. Т. 16. 